\title{
Characterisation of Nature-Based Solutions for the Built Environment
}

\author{
Yangang Xing ${ }^{1, *}$, Phil Jones ${ }^{1}$ and Iain Donnison ${ }^{2}$ \\ 1 Welsh School of Architecture, Cardiff University, Cardiff CF10 3XQ, UK; JonesP@cardiff.ac.uk \\ 2 Institute of Biological, Environmental and Rural Sciences (IBERS), Aberystwyth University, \\ Aberystwyth SY23 3JG, UK; isd@aber.ac.uk \\ * Correspondence: xingy5@cardiff.ac.uk or xygnet@hotmail.co.uk; Tel.: +44-29-2087-0373
}

Academic Editor: Davide Geneletti

Received: 1 October 2016; Accepted: 16 January 2017; Published: 20 January 2017

\begin{abstract}
Nature has provided humankind with food, fuel, and shelter throughout evolutionary history. However, in contemporary cities, many natural landscapes have become degraded and replaced with impermeable hard surfaces (e.g., roads, paving, car parks and buildings). The reversal of this trend is dynamic, complex and still in its infancy. There are many facets of urban greening initiatives involving multiple benefits, sensitivities and limitations. The aim of this paper is to develop a characterisation method of nature based solutions for designing and retrofitting in the built environment, and to facilitate knowledge transfer between disciplines and for design optimisation. Based on a review of the literature across disciplines, key characteristics could be organised into four groups: policy and community initiatives, multiple benefits assessment, topology, and design options. Challenges and opportunities for developing a characterisation framework to improve the use of nature based solutions in the built environment are discussed.
\end{abstract}

Keywords: green roofs; green walls; urban green infrastructure; built environment; urban retrofitting; design optimisation; ecosystem services; nature-based solutions; climate; health; well-being

\section{Introduction}

The current levels of intensive and rapid urbanisation are placing great pressure on the natural environment, including from increased pollution, resource depletion, flood risk, elevated temperature and decreased biodiversity. To plan and design sustainable urban retrofitting actions to counteract these effects is a complex task. Interactions between the natural environment, and social and economic conditions need to be examined in a holistic way. Singular linear approaches can only provide short-term economic profit to a few at the expense of the longer term transformative potential of sustainable urban development actions [1,2]. A number of comprehensive sustainability assessment schemes have been developed such as BREEAM (Building Research Establishment Environmental Assessment Method) and LEED (Leadership in Energy and Environmental Design). More specifically community-based schemes including BREEAM Communities (BREEAM-C) and LEED for Neighbourhood Development (LEED-ND) have been promoted. However limitations exist as these schemes focus on internal sustainability; so that environmental and socio-economic impacts occurring outside the development project's geographical boundary, such as embodied emissions, are only included to a limited extent [3]. The complexities of urban greening solutions have not yet been adequately explored in the academic literature or in certification schemes (such as BREEAM or LEED). A new framework specifically focused on the characterisation of nature-based solutions in the built environment is therefore needed to improve collaboration between research disciplines and enable the integration of design, planning and assessment processes. 
In contrast to conventional urban development solutions, nature-based actions offer simultaneously a wide range of sustainability benefits, including urban heat island mitigation, enhanced biodiversity, community pride and cohesion, and improvements in human health and wellbeing. A number of urban greening tools have been developed, such as the Berlin Biotope Area Factor [4], the Malmo Green Factor (GF) [4], the Seattle Green Factor (SGF) [5], and the Poland Ratio of Biologically Vital Area (RBVA) [6]. These green area indicators are defined as a ratio of the area covered by greenery, open water, permeable paving and storm water infiltration, etc. compared to the total site area. Researchers have also used green space per capita as an indicator within Chinese urban ecosystems (currently $40 \mathrm{~m}^{2}$ per capita with a target of $60 \mathrm{~m}^{2}$ per capita) [7]. An alternative approach has been the Green Plot Ratio (GnPR), which is the average leaf area index (LAI), i.e., the total single-side leaf area of the greenery on the site [8]. However, research reveals that these indices do not directly relate to the major residents' needs of social interaction and recreation [6], and that there is a lack of adequate outcome monitoring schemes [9]. Instead of focusing on target values, there is therefore a need to develop green spaces where the functionality matches the cultural and societal needs [10]. In order to mitigate unintended negative consequences [11-13], new holistic characterisation methods, to identify, analyse and maximise sustainability potentials of urban initiatives are needed.

Researchers have attempted to develop a generic classification of ecosystems services. For example Ahern (1995) suggested that green infrastructure elements could be summarised according to scales, goals, and landscape [14]; whilst de Groot (2002) classified ecosystems according to their functions, e.g., production of goods and services including climate regulation and habitat. Researchers have developed a reporting framework consisting of four main types of green space (with 26 sub-categories): amenity, functional, semi-natural habitats and linear [15]. However, typologies are descriptive tools, and provide limited insight into intervention strategies for advancing green infrastructure adoption [16].

There is a Pan-European target to restore at least $15 \%$ of degraded ecosystems by 2020 [17]. However, it is not clear how standard measurement procedures will be created to establish baselines and to assess subsequent performance. In contrast to high value ecological green spaces, such as nature reserves, urban greening actions have characteristics which are influenced by the surrounding built environment (so called grey infrastructure) and social systems. Urban specific metrics to assist in the evaluation of potential benefits of urban greening actions are urgently needed to enable urban greening actions to become mainstream. As most towns and cities have limited spaces for green planting more research is needed to understand the specific urban ecosystem service benefits to justify their maintenance and expansion. Integration of green and grey infrastructures is key for nature-based urban solutions [18,19]. For integrated planning and evaluation of urban green retrofitting actions, it is crucial to establish a holistic characterisation framework (including topology, design options, benefits and policy, and community innovation) to collect and communicate knowledge. Currently, there is a lack of a comprehensive classification for green infrastructure [20]. There is therefore a risk that the absence of holistic approaches to the classification and evaluation of urban greening actions is undermining credibility and deployment.

The aim of this paper is to develop a characterisation framework for the greening of spaces around or on buildings. The characterisation framework includes the following four components: (1) an integrated community participation and policy framework; (2) key features of the multiple benefits of urban greening actions (further categorised into ten groups, with a summary of the relevant studies and measurements); (3) a simplified built environment greening topology; and (4) a set of streamlined design options. The paper concludes with a discussion of the key challenges and opportunities to assist in the planning, design and evaluation of nature based solutions for built environment.

\section{A Generic Characterisation Process: From Community Initiatives to Policy Framework, and from Multiple Benefits Assessment to Design Optimisation}

Early initiatives involving urban re-greening actions were centred on community development. For example, the Garden City Movement proposed by Sir Ebenezer Howard in the United Kingdom 
promoted self-contained communities surrounded by "greenbelts", containing elements of residences, industry, and agriculture [21]. The size of contemporary cities is much larger than Howard's idealised Garden City of 32,000 people on a site of 6000 acres (2400 ha), and consequently there are higher levels of pollution and energy consumption. Nevertheless, the Garden City movement is seminal in urban greening initiatives. In the late 1970s, Seymour advocated more self-reliant lifestyles [22] and a number of communities formed nurturing self-sufficient living and caring for the Earth. However, it can be extremely difficult to achieve 100\% self-sufficiency. A pragmatic "more self-sufficient" approach has been adopted as a more realistic target for contemporary communities inspired by Seymour [23]. Architect Christopher Alexander stressed the participation of owners and users in the making of communities, claiming that all town and city planning should be from the bottom-up, done by neighbours for neighbourhoods [24]. This philosophy could also lead to wider engagement in terms of participatory planning in urban greening actions. Although studies have identified positive outcomes of participatory urban planning and design approaches, such approaches have been criticized for reinforcing power relationships and for supporting elite views. Therefore care is needed to also obtain input from under-presented stakeholders $[13,24]$. Participatory planning processes can be enhanced by clear and transparent communication of potential actions to assist in the identification and promotion of community initiatives as a base for nature based urban solutions.

In addition to community initiatives, government policies play a significant role in shaping green actions. Polices and incentives can be clustered according to the targeted greening solutions, such as green roof, green walls, and vegetated swales [25,26], or to the targeted benefits such as urban heat island mitigation, and stormwater management [27]. Recent advances in roof greening in Switzerland and Germany have been attributed to the creation of the appropriate policy environment. In Switzerland, Federal Law requires agencies to apply the 'Swiss Landscape Concept' when commissioning or rehabilitating federal buildings and installations, and in Germany $43 \%$ of cities offer financial incentives for roof greening [25]. Canada's city of Toronto adopted a Green Roof by-law in 2009 which applies to new commercial, institutional and many residential development applications [26]. A number of UK cities have also developed their own urban greening policy initiatives [27]. Green policy initiatives can be categorised into two types: regulatory legislation (mandating for the public or private sectors the planting in, on or around buildings), and incentive-based initiatives targeted at developers and building owners. The types of incentives vary and include low-interest loans, design and installation grants, tax and fee rebates, and expedited permit approval processes. Complex ownership structures of green landscapes can exist, and these need to be carefully reviewed as they can be a critical factor in determining economic viability and in developing policy frameworks [15]. Researchers have argued for a seamless process of planning and implementation across scales and jurisdictional boundaries that makes sense in terms of benefits and community participation [28,29]. Recently, holistic nature based urban solutions have been promoted in a number of pioneering research and innovation projects: such as the VegDUD programe funded by the French Research Agency [30] and the European Climate KIC Blue Green Dream project [31].

Most of the unused space in towns and cities is on the exterior walls and roofs of buildings. One obvious way to instate green space in the urban environment therefore is to integrate vegetation with buildings. Often, buildings that are subject to regulations are also eligible for an incentive offered by the same governing bodies. However, practical issues, including the availability of finance and the identification of benefits need to be promoted. It is also important to streamline initiatives at the levels of community, policy framework and investment. In other words, nature-based urban actions require measurements and assessment schemes that are holistic.

In this paper, we describe an integrated characterisation framework (Figure 1) to aid the mainstreaming of urban green planning, design and retrofit. This framework comprises four phases: joint initiatives (bottom up, community initiatives; and top down, policy frameworks); multiple benefit assessment (described in Section 3); urban greening actions topology (described in Section 4), and design optimisation (incorporating choice of plants, growing medium, and subsequent maintenance, 
described in Section 5). This framework aims to promote a virtuous circle from the integration of joint initiatives, identification of potential actions, delivery of an integrated design, realisation of multiple benefits, and eventually an improved urban greening action informing future initiatives, and promoting an iterative learning loop to ensure lessons are learnt and accumulated results are assimilated for greater impact.

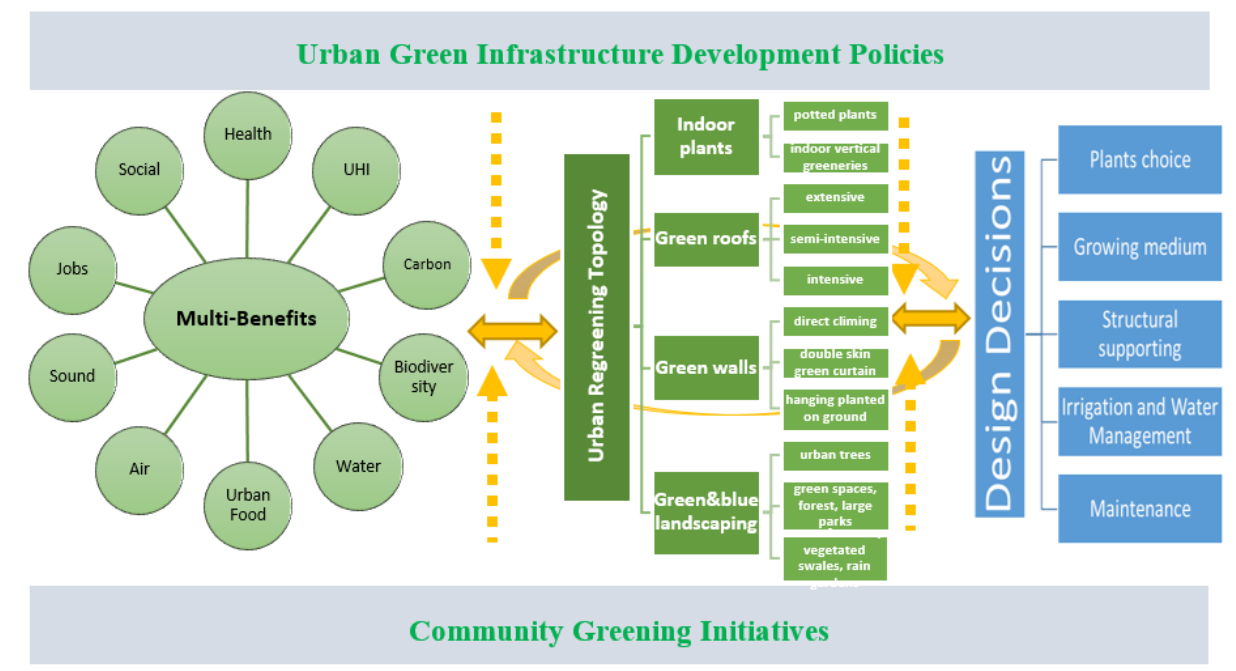

Figure 1. A generic characterisation framework for exploring nature based built environment solutions.

\section{Dynamic Multiple Benefits of Nature Based Urban Actions}

Urban green infrastructure can offer multiple benefits simultaneously. Although the existing evidence is fragmented, studies are revealing dynamic ecosystem services benefits. To optimise and realise the potentials of urban greening actions, it is important to consider sustainability features over the whole life cycle of the project. To date the evidence base for the multiple benefits of urban green infrastructure is complicated and limited. Based on previous research in sustainability impact assessment [29-31], and a review of the urban green infrastructure literature (Table 1), ten categories of potential benefits have been identified (Figure 2).

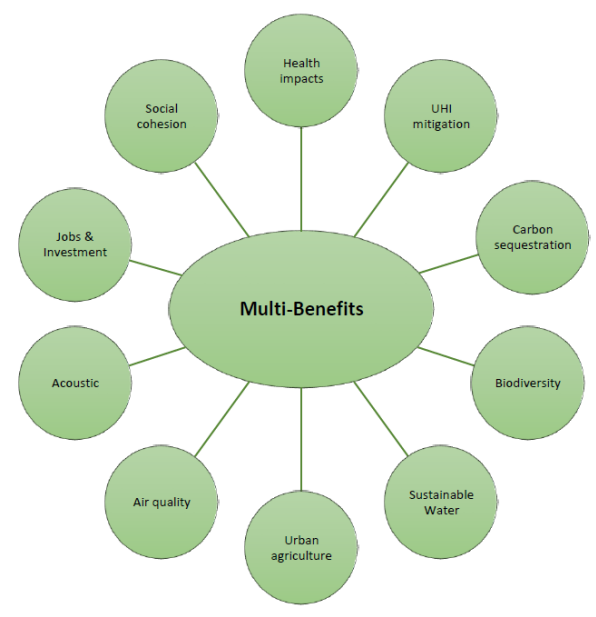

Figure 2. Potential multiple benefits of nature-based urban solutions.

\subsection{Health Benefits}

Physiological and psychological health benefits of nature has previously been described [32]. Modification of the built environment to provide green space offers opportunities for beneficial 'green 
exercise', improving mental and physical health including a reduction in obesity, headaches, dryness and itchy skin, and increase in pain tolerance [32]. A high level of urbanisation being associated with an increased risk of psychosis and in depression of both women and men [33]. A move to greener urban areas have been associated with sustained mental health improvements, suggesting that environmental policies to increase urban green space may have sustainable public health benefits [33]. A number of research activities have explored the wider psychological health benefits of green infrastructure [34]. However, it has also been argued that such observations may not indicate a causal relationship and could be explained by other factors. For example, socially deprived areas typically contain low levels of green space. Nevertheless, it has been established that the additive effects of a peaceful natural environment and physical activity contribute to better mental health [35]. Experiments show that indoor plants can improve concentration and productivity, and lead to direct benefits for mental functioning [36,37]. In particular, the benefits of indoor plants are often overlooked in green building actions.

Table 1. Categorisation of key benefits and measurement examples for urban green infrastructures.

\begin{tabular}{|c|c|c|c|}
\hline Categories & Examples of Measured Key Benefits & $\begin{array}{l}\text { Examples of Quantification } \\
\text { and Data Collection Methods }\end{array}$ & References \\
\hline Health impacts. & $\begin{array}{l}+ \text { Physiological and } \\
\text { psychological benefits. }\end{array}$ & $\begin{array}{l}\text { Survey, GIS mapping } \\
\text { and models. }\end{array}$ & [34-37] \\
\hline $\begin{array}{l}\text { UHI effects, mitigation } \\
\text { and energy saving. }\end{array}$ & $\begin{array}{l}\text { +UHI effects mitigation. } \\
\text { +Heating and cooling for } \\
\text { energy saving. }\end{array}$ & $\begin{array}{l}\text { Laboratory testing. } \\
\text { Outdoor test cells. } \\
\text { In situ measurement. } \\
\text { Computer simulation. }\end{array}$ & [38-44] \\
\hline Carbon sequestration. & $\begin{array}{l}\text { +Photosynthesis for } \\
\text { carbon sequestration. }\end{array}$ & $\begin{array}{l}\text { Laboratory testing, e.g., } \\
\text { gravimetric method }\end{array}$ & [45-49] \\
\hline Biodiversity. & $\begin{array}{l}\text { +Type and size of plants and insects, } \\
\text { other species, green and } \\
\text { brown spaces. }\end{array}$ & $\begin{array}{l}\text { Site observation. } \\
\text { GIS mapping }\end{array}$ & [50-55] \\
\hline $\begin{array}{l}\text { Sustainable water } \\
\text { management. }\end{array}$ & $\begin{array}{l}\text { +Stormwater retention. } \\
\text { +Water quality. }\end{array}$ & $\begin{array}{l}\text { Test rigs and modelling of } \\
\text { runoff retention. } \\
\text { Laboratory testing of pollutants. }\end{array}$ & [56-63] \\
\hline Urban agriculture. & $\begin{array}{l}\text { + Local food supply. } \\
\text { +Pollination services and urban honey. }\end{array}$ & $\begin{array}{l}\text { Economic value. } \\
\text { Food miles saved. }\end{array}$ & [64-72] \\
\hline $\begin{array}{l}\text { Air quality through } \\
\text { bio-infiltration. }\end{array}$ & +Percentage of air pollutants reduced. & $\begin{array}{l}\text { In situ monitoring. } \\
\text { Laboratory testing. } \\
\text { Computer modelling. }\end{array}$ & {$[46,59,62,73-80]$} \\
\hline Acoustic comfort. & $\begin{array}{l}\text { +Acoustic insulation }(\mathrm{dB}) \\
+ \text { Noise pollution reduction and } \\
\text { sound environment. }\end{array}$ & $\begin{array}{l}\text { Laboratory testing. } \\
\text { In situ measurement. }\end{array}$ & [81-83] \\
\hline $\begin{array}{l}\text { Job and investment } \\
\text { opportunities. }\end{array}$ & $\begin{array}{l}\text { +Positive return on investment. } \\
\text { +Job opportunities }\end{array}$ & $\begin{array}{l}\text { NPV Calculation, surveys } \\
\text { and interviews. }\end{array}$ & [84-89] \\
\hline $\begin{array}{l}\text { Social cohesion } \\
\text { and pride. }\end{array}$ & $\begin{array}{l}\text { +Uses of urban parks by } \\
\text { different groups. } \\
\text { +Attachment to the community and } \\
\text { increased interactions. }\end{array}$ & $\begin{array}{l}\text { Survey, observation, interviews } \\
\text { and spatial mapping. }\end{array}$ & [90-95] \\
\hline
\end{tabular}

\subsection{Urban Heat Island Effect Mitigation Improving Thermal Comforts and Energy Saving}

The impacts of the intensification of urban buildings and thermal mass on the local microclimate include, alteration of local wind patterns, formation of clouds and fog, increased humidity and changes in the precipitation rate. This phenomenon has been studied in detail as the urban heat island (UHI) effect by Oke and colleagues [38]. Givoni (1994) examined the relationships between building design, thermal comfort and climate, and proposed a number of passive design approaches [39]. Recently, researchers have explored the potentials of urban green infrastructure to minimise UHI effects improving thermal comforts through the modification of microclimate including wind speed, relative humidity, and reflection of incoming solar radiation and terrestrial radiation from the ground and other surfaces. One of the best documented effects of green surfaces is the direct and indirect benefits arising from a reduction in the heating and cooling demands of buildings and improving 
thermal comforts. A number of case studies have been conducted to demonstrate UHI mitigation benefits. Djedjig (2012) described approaches for modelling green roof heat and mass transfer using partial differential equations to calculate heat balance based on measurement [40]. Mirzaei (2015) reviewed different modelling tools to investigate UHI effects using tools ranging from the building scale (i.e., energyPlus) through to the meso-city scale (i.e., Town Energy Balance Model) [41]. The drivers for studying UHI effects vary from energy saving, adaptation to future temperature prediction and urban ventilation surface manipulation. For example, it was shown that a pond can provide considerable cooling, and flowing water has a larger effect than stagnant water [42]. During winter, green roofs can act as insulators, but this benefit is dynamic depending on climate zone and building characteristics. For example, contrary to most studies, intensive heat losses could be induced during winter sunny days in Hong Kong [43], which was largely due to climate variation and specific building construction. An outdoor thermal comfort study showed a moderate effect of green roofs on the surrounding microclimate, but a larger contribution when combined with vegetation at pedestrian level [44]. Compared to urban trees and parks, the limiations of green roofs and green walls still need to be explored for design optimisation. In summary, to quantify UHI reduction and energy saving potentials of nature based solutions, detailed sensitivity analyses are required.

\subsection{Carbon Capture and Sequestration}

Carbon can be sequestered in plants and soil. Research has revealed that on average $2.5 \times 10^{3} \mathrm{~g} \cdot \mathrm{m}^{-2}$ of carbon is stored in domestic gardens, with $83 \%$ in soil (to $600 \mathrm{~mm}$ depth), $16 \%$ in trees and shrubs and only $0.6 \%$ on average in grass and herbaceous plants [45]. The carbon fixation rate depends on a number of factors, such as the concentration of carbon in the air, the extent of natural and artificial lighting [46] and the age of trees. Younger plants tend to have higher sequestration rates than older plants which is especially relevant for long lived trees. The carbon storage of trees can be calculated by estimating the dry weight of vegetation as a certain percentage of the fresh-weight. Carbon sequestration rates can be estimated based on the annual growth of different plants [46] including trees [47]. Research revealed that $375 \mathrm{~g}$ of Carbon could be sequestered by one square metre of extensive green roof in Detroit, USA [48]. Greenhouse gas emissions vary spatially and temporally, as does soil soluble reactive phosphorus (e.g., being higher in wetlands than in forest and prairie). Careful consideration of small-scale variability of such factors is therefore needed to develop more accurate carbon sequestration estimations [49].

\subsection{Biodiversity}

Biodiversity has been defined in various ways, but the term has generally been used in a very comprehensive manner to mean the variability of life (composition, structure and function), and represented as an interlocked hierarchy of elements on several levels of biological organization, at all levels of life from genes to communities and all spatial and temporal scales [50,51]. Biodiversity indicators have also been developed to measure the connectivity of green spaces; however, they are rarely used due to the difficulties of data collection [52]. An indicator of biodiversity is the area of green space and this can be refined further by incorporating a measure of heterogeneity [52], for example by calculating the relative proportions of bare ground, turf grass, rough grassland, herbs, shrubs, trees and the built environment. It has been reported that the more even the distribution of habitats the higher the biodiversity index [52].

Cities can be richer in plant diversity than farmland dominated by monoculture agriculture where a limited number of crop species (arable or improved grassland) are grown [52]. Urban habitats can assist in the conservation of rare and endangered native species, as well as harbouring many nonnative species, both capable of delivering ecosystem services, social benefits, and potentially biodiversity conservation. For example, Baldock et al. [53] reported that bee species richness, important for pollinator services, was higher in urban areas than farmland [53]. In another study, Mason [54] reported that whilst bird species richness was similar between housing developments in a small town 
and adjacent arable farmland, bird numbers were much lower in the farmland. Green spaces in cities are usually split up into small patches surrounded by built-up areas. Biodiversity has a very complex relationship with the physical and biological characteristics of a habitat; therefore, any biodiversity indicators on land cover data alone are likely to act only as a rough guide. Citizen Science approaches have been proposed and successfully used for data collection and analysis [55,56]. Biodiverse green roofs are generally topographically variable and include habitat features such as logs, or large stones ("brown roof" features) to provide microhabitats for organisms such as spiders and beetles. Birds can also make use of these features for perching while searching for food. However, such more diverse roofs are may require additional structural support especially if being retrofitted onto existing buildings. Brown roofs may also require different maintenance regimes and may not always be considered more aesthetically pleasing when compared to conventional green roofs.

\subsection{Sustainable Water Management}

Water transpiration from plants provides a significant flow of water into the atmosphere. Green infrastructure can provide interception and storage of rainfall at source and can reduce diffuse pollution by enhancing sediment retention, helping to create so called sponge cities. Plants are effective at intercepting aerial drift of pesticides that would otherwise enter watercourses. Compared to traditional piping systems, a study reveals that rain gardens were found to be a more favourable option, both financially ( $42 \%$ cost reduction) and environmentally ( $62 \%-98 \%$ impact reduction) [57]. It has been argued that rain gardens can be incorporated into current building design and drainage regulations, and can also be easily retrofitted [58]. The reduction by green roofs of annual storm runoff generally ranges from $50 \%$ to $100 \%$, depending on the roof system, substrate composition and depth, roof slope, plant species used, pre-existing substrate moisture, the intensity and duration of the rainfall [59], and antecedent dry weather period [60]. However, green roofs alone cannot solely be relied upon to provide complete stormwater management at the watershed scale. The use of green roofs can be helpful to mitigate the effects of rainfall events especially if green roofs are widely implemented at the catchment scale [61]. The water quality of the runoff from a green roof is also dependent on multiple factors including substrate composition, substrate depth, plant selection, age of the roof, fertilization and maintenance practices, and the volume of rainfall. Careful nutrient management of new green roofs is needed to reduce negative impacts of water pollution [62], particularly in dry climates [63]. It is demonstrated that established vegetation and substrates can improve the water quality of runoff by absorbing and filtering pollutants [59].

\subsection{Urban Agriculture}

Urban agriculture (whether indoor, garden plots or on walls and rooftops) can provide city-dwellers with a source of fresh food, an improved diet including nutrition, and potentially an important boost to household budgets. Researchers have also used the term "vertical farming" [64], "Zero-Acreage Farming" (ZFarming) [65], "Continuous Productive Urban Landscapes" (CPUL) [66], or "Plant Factory" [67] to describe forms of urban agriculture. Calculating the amount of locally produced food distributed to low income citizens through community organizations, such as food banks, can provide an estimate of the food security benefits related to urban agriculture. In a more commercial setting, a study showed that growing herbs on the $195 \mathrm{~m}^{2}$ rooftop garden of a hotel in Vancouver provided an estimated $\$ 25,000$ to $\$ 30,000$ annual saving in food costs for the hotel restaurant [68]. Green roofs are potentially valuable sites for ecosystem services related to production including pollination and bee conservation in urban areas, particularly if planted with diverse native forms to provide foraging resources, and designed to accommodate bees (both native and exotic) with different nesting habitats [69,70]. Urban honey can also provide another income stream for households or businesses, and beekeeping again represents another way for those living in cities to interact with nature. As the number of green roofs in cities increases, the characteristics of their designs, including the vegetation type and diversity, could have a significant impact in shaping local urban bee 
communities. It is reported that green roofs flowers can provide important habitant and pollen for urban honey bees [71]. Researchers investigated antibacterial medicinal properties of urban honeys [72].

\subsection{Air Quality through Bio-Infiltration}

Vegetation can remove pollutants in a number of ways [73]. For example, plants can take up gaseous pollutants through their stomata, intercept particulate matter with their leaves, and are capable of breaking down certain organic compounds, such as poly-aromatic hydrocarbons, in their tissues or this can occur in the soil. In addition, by reducing the need for air conditioning, a lower requirement for energy results in lower $\mathrm{CO}_{2}$ emissions from power generation [74]. Urban vegetation can also indirectly reduce air pollutants by lowering surface temperatures through transpiration cooling and by providing shade, which in turn decreases photochemical reactions that form pollutants such as ozone in the atmosphere [59]. Researchers have reported that planting of vegetation in street canyons can reduce street-level concentrations of pollutants in those canyons by as much as $40 \%$ for $\mathrm{NO}_{2}$ and $60 \%$ for PM 10 particulates (Pugh, MacKenzie, Whyatt 2012). Green roofs or walls in polluted areas can therefore help form a part of an air quality management programme. However, the planting of green infrastructure needs to be guided by an awareness of the issue of legacy pollutants so that appropriate recommendations can be made [76]. Indoor air pollution is commonly two to five times higher and sometimes as much as 100 times more concentrated than in the air outside [77]. Indoor plants can simultaneously deplete $\mathrm{CO}_{2}$ and volatile organic compounds (VOCs), and thus have potential to improve indoor air quality $[78,79]$. However plants can also produce pollen and biogenic volatile organic compounds that can be a source of ozone and fine particles which represent a risk for health [79]. Studies indicate that through appropriate lighting and spatial arrangement of plants (plantscape), the $\mathrm{CO}_{2}$ and other pollution mitigation properties of plants can be optimized for improvement indoor air quality $[46,80]$.

\subsection{Acoustic Comfort}

Urban vegetation has important sound insulation properties and is often employed for noise reduction measures in cities. Laboratory tests show that green walls have significant potential as a sound insulation tool for buildings and a weighted sound reduction index (Rw) of $15 \mathrm{~dB}$ and a weighted sound absorption coefficient (a) of 0.40 can be achieved [81]. A field experiment showed the mean noise reduction coefficient of established green roof plots over a two year period, with distinctly different plant communities in substrate depths of $50 \mathrm{~mm}$ to $200 \mathrm{~mm}$, ranged from 0.20 to 0.63 [82]. Researchers have also investigated sound absorption properties of plants for indoor acoustic treatment. One study established that the substrate is able to absorb up to $80 \%$ of acoustic incident energy, and the presence of the tested plants enhanced the absorption [83]. Researchers have also argued that it is not simply noise levels that are important; context, source, distance, temporariness and control over noise are all relevant to annoyance and whether people would want to see a particular sound eliminated from their soundscape [84]. A holistic approach for sound abatement is therefore required to reconfigure green spaces. Nevertheless, urban green infrastructure combining building design and retrofitting actions (such as insulation and spatial planning) can play a significant role in sound attenuation and the creation of a pleasant and healthy soundscape.

\subsection{Jobs and Investment Opportunities}

It can be assumed that as more cities invest in green infrastructure, then more opportunities will be created for trained workers in green infrastructure employment, as well as in the associated supply chain, including nurseries, environmental restoration, management and conservation. Demand for green-collar labour is therefore predicted to increase, and methods are being developed to determine the impact of green training programmes on local communities [85]. Economic benefits of green urban spaces have been identified [86,87] and reveal that such infrastructure can provide a competitive advantage at local scales through inward investment, visitor spending, new job creation, and health 
and environment improvement. Using the Net Present Value (NPV) calculation method, it has been demonstrated that a majority of the ecological restoration projects analysed provided net benefits, not only being profitable but also creating high-yielding investments $[88,89]$.

\subsection{Social Cohesion and Pride}

Natural features and open spaces play an important role in residents' feelings of attachment towards their community, including by facilitating interactions with other residents [90]. The use of urban parks by different groups have been investigated using both quantitative (surveys) and qualitative methods (observations and interviews), and results indicate that urban parks are used as inclusive places where people of different ethnicities spend leisure time [91]. It has been argued that the valuation of ecosystems has long been dominated by monetary explanations, neglecting other social perspectives [92,93]. It is critical that the social value of green spaces [94,95], and the effective methods to engage different ethnic groups, need to be established to mainstream nature based solutions for urban regeneration and development of the inclusive economy.

\section{Discussion: Development of a Simplified Topology for Nature Based Solutions in the Built Environment}

Providing access to nature for growing urban populations poses unprecedented challenges in urban development. With less land available to build on, one promising solution is to construct greeneries in, on or around buildings. Analysis reveals there is no consensus on a comprehensive classification for green infrastructure [20]. Based on the location of the urban greenery, we have identified four meta-types of nature based urban actions indoor plants, green roofs, green facades and green and blue landscaping comprising trees, gardens, parks and water features (Figure 3).

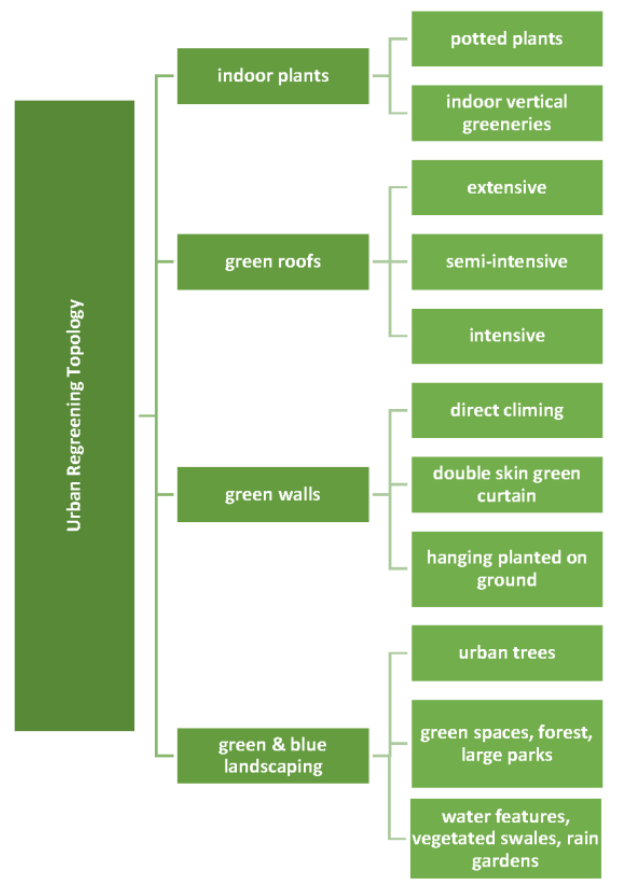

Figure 3. A Simplified typology of nature based urban actions.

\subsection{Indoor planting}

City dwellers spend the majority of their time indoors at home or work. Indoor plants represent a multi-function, low-cost, easily maintained, air-cleansing ventilation component [73]. Based on the growing medium, indoor plants are generally grouped into soil-based, non-soil based (such as hydroponic [96], aeroponic, or aquaponic [97]). In additional to conventional indoor potted plants, 
innovative indoor vertical greenery has also been investigated $[37,98]$. However, there is still a need to explore how indoor planting can be integrated into building services design.

\subsection{Green Roofs}

A number of measures to integrate plants with building facades exist. A green roof (sometimes referred to as a vegetated roof, eco-roof, or living roof) is a roof of a building that is partially or fully covered with a layered vegetation system comprising of plants, growing medium, waterproof membrane, additional layers such as root barriers, and drainage and irrigation systems (where the climate necessitates). La Roche and Berardi [99] have also proposed an active or smart green roof where the thermal mass of the green roof can be coupled or decoupled to help with cooling in the summer and heating in the winter. Green roofs range from edible and recreational roof gardens with raised beds and pots, to rolled-out green carpets, to shed roofs containing planting cells that are filled with soil or compost and planted up with low growing perennials and grasses. There are two major types of construction of green roof: trays and built up. Based on the depth of the substrate layer and the type of vegetation, green roofs can be divided into three main categories: extensive, semi-intensive and intensive. Most of the installed green roofs to date have less than $30 \mathrm{~cm}$ depth of substrate which has been considered as the current optimum [25]; however, it need to be further investigated according to local building and climates characteristics. A greater depth of green roof may increase functionality including ecosystem services provision but at the expense of a greater requirement for structural support.

\subsection{Green Walls}

Green walls can be divided into three main types: traditional green facade, where climber plants use the facade material as a support; double-skin green facade or a green curtain, with the aim of creating a double-skin or green curtain separated from the wall; and perimeter flowerpots, where, as a part of the composition of the façade, hanging pots or shrubs are planted around the building to create a green curtain [100-102]. Green walls can also be used for low level landscaping of car parks, services and for providing shade. Practitioners have been advocating vertical landscaping from green areas at ground level, linking to building facades combined with balconies, and roof areas [103,104], however, this concept has so far been rarely implemented.

\subsection{Urban Green and Blue Infrastructure}

The urban green and blue landscape (a network of green spaces, water and other natural features) is a vital element for sustainable urban greening actions. Urban green and blue landscapes include urban forest or street trees $[15,105]$ and urban lakes, rivers, canals, fountains and rain gardens. Urban blue infrastructure can effectively capture and treat stormwater, as on-site bio-retention facilities [106], and cool the city by evaporation and transportation of heat by rivers. Depending on the landscape, including soil structure and chemistry, urban greening actions can be developed based on an appropriate integration of site planning, plant selection, installation, and maintenance of trees in the challenging urban environment [107].

Sustainable urban greening is still in its infancy. A number of online databases are being developed for particular types of actions, such as green roof and wall directories [108,109]. However, indoor greening actions are often overlooked in research and practice. In addition, schemes to assess the multiple benefits of green actions need to be established with the aim of providing support at the very early planning stage. A topology of urban greening actions is illustrated in Figure 3 to provide a starting point to assist in the planning and design of urban green actions. Nevertheless, a topology needs to be further developed to provide generic pathways for community members, planners, designers and other key stakeholders to mainstream nature based solutions in their urban planning and design. 


\section{Built Environment Greening Design Decisions}

To make urban greening design decisions is a complicated undertaking. It has been argued that knowledge about the ecosystem should be clearly communicated and made easily accessible to policy makers, the general public and other stakeholders [110]. Design options are key in determining policy framework, assessing multiple benefits and engaging with community members [111]. In this paper, the key green design decisions (plants, substrate/supporting elements, irrigation and maintenance) are discussed and illustrated in Figure 4.

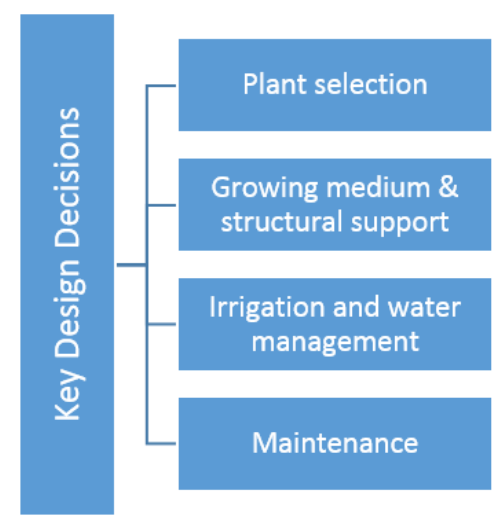

Figure 4. Key Built Environment Greening Design Decisions.

\subsection{Selection of Plants}

One of the key components in sustainable urban planning is the selection of plants and planted spaces $[8,52]$. Selection of appropriate plants is critical to the performance and survival of urban greeneries, but is potentially complex. In 2016, based on the first global assessment of the world's flora, it was estimated that the number of vascular plant species is 390,900, of which approximately 369,400 are angiosperms (or flowering plants). It was further estimated that $21 \%$ of plants are at risk of extinction [112] due to climate change and habitat loss. Great potential exists for plant selection for green infrastructure amongst the enormous diversity but as for other applications we are also at risk of losing species before we find a use for them. The selection criteria for choosing a plant for urban greening are: biodiversity, climate suitability, drought and stress tolerance, aesthetics, leaf area coverage, potential for cooling, and pollutant removal efficiency $[43,55,107,113]$. Plant characteristics influencing selection include rooting depth, perenniality vs. annuality and evergreen vs. deciduous. Typically, the more even the distribution of different types of habitats the higher the biodiversity index. Plant selection and growth pattern will also impact the subsequent maintenance required [114] and thermal performance, such as shading and evapotranspiration rates.

The impact of plant traits (such as leaf transpiration rate, leaf solar transmittance, leaf surface temperature and leaf coverage) can impact on the cooling effects of green walls. Leaf area index (LAI) is a commonly used parameter defined as the single side leaf area per unit area. Water stress tolerance has been considered as the priority for plant selection on extensive and semi-extensive green roofs, with probably aesthetic quality second. Sedum species (e.g., S. album, S. acre), with typical xerophytic characteristics, are the most widely used green roof plants due to the drought risk and exposed nature of extensive and semi-extensive green roofs [113]. Alternative plants have also been studied including broad leafed perennials, grasses and shrubs, and been shown to be promising alternatives in terms of surface coverage and protection from water runoff and increased cooling potential $[62,115,116]$. Sound attenuation provided by green roofs and green walls will depend on the thickness and type of substrate, plant community established and moisture content of the plants and substrate, as well as sound frequency [82]. 
There is a consensus over the general preference and aesthetic, affective and restorative qualities of greenery; however, different types of vegetation may be perceived differently. It has been argued that the more natural the green infrastructure, the more it is preferred. For example, a natural meadow roof was preferred over a turf counterpart which was more highly managed [117]. Green infrastructure is subject to change over time with potentially some or all of the original vegetation becoming lost and replaced by new species through natural seed dispersal. The development of functional landscape plants is potentially a new opportunity for plant sciences [118].

\subsection{Growing Medium and Structural Supporting Infrastructure}

The selection of appropriate types and volumes of substrates is necessary to realise the potential benefits of urban green infrastructure for thermal comfort [119-121], vegetation performance [119], and sound attenuation [82]. The use of locally available or recycled materials could reduce embedded energy in processing the materials and the consumption of natural materials. Researchers have investigated the possibilities of using recycled rubber from used tyres as a drainage layer in green roofs, substituting the porous stone materials currently used (such as expanded clay, expanded shale, pumice, and natural puzolana [122]. Ideally the supporting structure and growing medium need to be compatible with the natural settings and landscape.

For green wall and roof design, the robustness of the supporting structure is also an important element. A double-skin green façade, or green curtain, is often one of the preferred structural options since it requires minimum subsequent maintenance and can be easily assembled, disassembled, and integrated into the building maintenance schedule $[123,124]$. A similar option is a vine covered trellis suspended over a roof, known as a green cloak. It has been demonstrated that a green cloak can reduce maximum daily indoor temperatures by as much as $3.1^{\circ} \mathrm{C}$ during July in Maryland [125]. A life cycle analysis of support elements for vines reveals that resources used for a stainless steel support are roughly 10 times higher than supporting systems based on recycled plastic (HDPE), hard wood (FSC certificated) and coated steel [126].

\subsection{Irrigation and Water Management}

Irrigation is essential during establishment and potentially the first growing season. Equally overwatering or waterlogging can cause plants to die from a lack of oxygen to the roots. Artificial irrigation may also have negative impacts for water and energy conservation, especially in arid regions. Smart irrigation control technologies are proposed and need to be evaluated. Alternative irrigation sources (e.g., from use of grey water and rainwater harvesting) [127] and the control and monitoring of irrigation regimes can be used to maintain plants and maximise cooling effects [128]. Grey water discharged from the built environment usually consists of the effluent from lavatories, sinks, showers, or water fountains. It contains small amounts of nitrogen, phosphorus, BOD, detergents, salts and pathogenic bacteria, which can effect plant physiology, transpiration, and therefore thermal performance. Based on a laboratory experiment, it shows the average difference between the thermal resistance of clean water green roof and grey water green roof was $0.2 \mathrm{~m}^{2} \cdot \mathrm{K} \cdot \mathrm{W}^{-1}$ for ryegrass and $0.9 \mathrm{~m}^{2} \cdot \mathrm{K} \cdot \mathrm{W}^{-1}$ for periwinkle. Overall, grey water irrigation reduced the thermal resistance by $30 \%$ (i.e., ryegrass, the reduction was $28 \%$ and for periwinkle, the reduction was $32 \%$ ). [127]. Rain gardens, can offer local seasonal rainwater storage, as well as playing a role in the future development of irrigation systems. Currently, research on innovative irrigation systems for urban green infrastructure is in its infancy. Water efficiency should be a key indicator (e.g., consumption per unit area, and use of waste or rain water) in developing urban green actions.

\subsection{Maintenance}

Urban green infrastructure involving building envelopes requires structural and horticultural maintenance activities. Some plants may become stressed and only partially or never recover after an extreme weather event leaving gaps [129]. On the other hand, overgrown vegetation arising from 
a lack of maintenance can have a negative impact by increasing the fear of crime; although such overgrown spaces may be better for biodiversity. Major plant 'failure' (death or poor cover) is likely to arise from factors such as irrigation failure, drainage failure, inappropriate plant selection, poor plant quality, substrate issues and problems in installation and establishment, as well as a lack of plant management $[130,131]$. Maintenance costs mainly consist of optional water pipes, supporting structural maintenance, plant replacement and pruning, mowing, weeding and watering [27]. However, Seymour and Seymour (1976) suggested horticulture activities are not 'economic' but should instead be considered as recreational and for pleasure. Social and Therapeutic Horticulture is an emerging therapeutic movement to promote health and wellbeing [132]. Nevertheless, the need for maintenance of urban green infrastructure is a key implementation barrier and research in this area is limited [133], with whole life commissioning and monitoring needing to be considered as a key design element.

\section{Discussion and Conclusions}

The loss and limited availability of green spaces in metropolitan areas, due to the rapid urbanisation over recent decades, has led to growing concerns for the future sustainability of cities. Urban regeneration actions which rely on existing technologies and focus on single functions may neglect or inadequately explore the potentials of sustainable urban green solutions. Urban greening actions can enable multiple ecosystem services and societal benefits including: climate change adaptation, community engagement, human health and wellbeing, and social cohesion and pride. However, nature-based solutions are often overlooked in building design and planning due to the complexity in their design and evaluation. To mainstream nature-based built environment actions into urban planning represents a challenge. There is a lack of research in identifying pathways to put into place the green actions for the necessary building planning and design. There is also a need to develop a common protocol to illustrate key driving factors for nature based solutions in the built environment.

A key challenge is how to establish a holistic framework. In this paper, a generic characterisation framework has been developed to illustrate four groups of major driving factors behind the transition pathway: (1) Green initiatives (community, policy and investment); (2) Key categorisation and examples of measured benefits; (3) A simplified topology of nature based solutions in the built environment; and (4) Key design options (plant species selection, maintenance, monitoring, and supporting infrastructure). To link the four groups of major driving factors, the following are needed: community participatory planning, multi-disciplinary measuring and inter-disciplinary learning, which forms the framework for mainstreaming nature based solutions in the built environment.

Communities play an essential role in restoring urban ecological systems, not only related to maintaining greenery, but also for the monitoring, empowerment and evaluation of green actions. Communities have been focal points since early attempts to address urban issues using nature-based solutions $[21,22,24]$. Over the past decade there has been a rapid increase in the number of Citizen Science initiatives which offers an attractive solution for on-going monitoring [134-136], and the engagement and empowerment of communities to lead urban green actions. A participatory planning process is critical in identifying and mainstreaming nature-based solutions in towns and cities. Based on previous participatory planning exercises $[13,136]$, mobile phone-based data collection tools [136] and new modelling tools to improve analysis and visualization [13] of the benefits of urban greening is critical to support stakeholders in decision making. This therefore creates the need for a visualisaton tool to support the optimisation of nature based urban design and retrofitting actions.

A number of measurement methods have been reviewed and presented in this paper. Holistic evaluations of multiple benefits are becoming increasingly important in the mainstreaming of nature-based solutions for urban planning. Few people who design green actions go on to monitor and assess their performance after construction. As a result, good cases remain unnoticed, or the same mistakes risk being repeated [137]. Therefore, post construction evaluation is key to maximise benefits, and to avoid or minimise repeated mistakes and missed opportunities. However, affordable equipment and standardised test rigs and procedures need to be developed for testing in a controlled environment 
and for in situ monitoring. Furthermore, there is a need to develop an accreditation scheme to assess key components of urban greening actions and to help local authorities to set minimum requirements for green infrastructures. The ten key categories of the benefits described in this paper represent a starting point for such an accreditation scheme. Monitoring of existing nature based solutions will allow a better assessment of the spatio-temporal variability of benefits/performance which could be significant but are often overlooked. Data is particularly needed to develop and validate models that can be used to evaluate green infrastructure benefits/performance. Such quantifications could be used to improve existing sustainability assessment schemes (such as BREEAM and LEED) and their promotion of sustainable nature based solutions.

To design and evaluate the performance of urban solutions is complex with existing evidence and classifications fragmented. The performance of different types of green infrastructures vary in different seasons, climate zones, and with different maintenance practices. Over 400,000 vascular plant species have been identified [112], and so the number of urban green action designs based on combinations of plants, substrates and other supporting elements is enormous. Sustainable nature based urban design and retrofitting actions in, on, or around buildings are still in their infancy with significant amounts of new data needed to be collected and analysed by multi-disciplinary teams [138].

There is an instinctive bond between human beings and other living systems [139] which offers a powerful driving force to re-green our cities. Learning from, and establishing a new relationship with, nature is needed to mainstream nature based solutions in the built environment. The characterisation framework described in this paper, provide opportunities to develop future empirical studies to generate reference data for design optimisation based on learning between the disciplines of plant science, ecology, urban climate, building physics, engineering, biology, urban planning, and architecture.

Acknowledgments: The Authors acknowledge the financial support of the Welsh Assembly Government and Higher Education Funding Council for Wales through the Sêr Cymru National Research Network for Low Carbon, Energy and Environment.

Author Contributions: Yangang Xing, Phil Jones, and Iain Donnison conceived the research. Yangang Xing wrote the paper. Phil Jones and Iain Donnison provided support in the manuscript preparation including knowledge and reviewing. Iain Donnison provided support in substantial editing.

Conflicts of Interest: The authors declare no conflict of interest.

\section{References}

1. Vale, B.; Vale, R. Domestic energy use, lifestyles and POE: Past lessons for current problems. Build. Res. Inf. 2010, 38, 578-588. [CrossRef]

2. Baker, S.; Eckerberg, K. Ecological restoration success: A policy analysis understanding. Restor. Ecol. 2016. [CrossRef]

3. Wangel, J.; Wallhagen, M.; Malmqvist, T.; Finnveden, G. Certification systems for sustainable neighbourhoods: What do they really certify? Environ. Impact Assess. Rev. 2016, 56, 200-213. [CrossRef]

4. Hagen, K.; Stiles, R. Contribution of landscape design to changing urban climate conditions. In Urban Biodiversity and Design; Müller, N., Kelcey, J.G., Werner, P., Eds.; Wiley-Blackwell: Oxford, UK, 2010; pp. 572-592.

5. Hirst, J.; Morley, J.; Bang, K. Functional Landscapes: Assessing elements of Seattle Green Factor. The Berger Partnership PS, 2008. Available online: http://www.seattle.gov/dpd/cs/groups/pan/@pan/documents/ web_informational/dpds021359.pdf (accessed on 7 January 2017).

6. Szulczewska, B.; Giedych, R.; Borowski, J.; Kuchcik, M.; Sikorski, P.; Mazurkiewicz, A.; Stańczyk, T. How much green is needed for a vital neighbourhood? In search for empirical evidence. Land Use Policy 2014, 38, 330-345. [CrossRef]

7. Xiao, M.; Lin, Y.; Han, J.; Zhang, G. A review of green roof research and development in China. Renew. Sustain. Energy Rev. 2014, 40, 633-648. [CrossRef]

8. Ong, B.L. Green Plot Ratio An ecological measure for architecture and urban planning. J. Landsc. Urban Plan. 2003, 63, 197-211. [CrossRef] 
9. Keeley, M. The Green Area Ratio: An urban site sustainability metric. J. Environ. Plan. Manag. 2011, 54, 937-958. [CrossRef]

10. Kabisch, N.; Haase, D. Green justice or just green? Provision of urban green spaces in Berlin, Germany. Landsc. Urban Plan. 2014, 122, 129-139. [CrossRef]

11. Shrubsole, C.; Davies, M.M.; May, N. 100 Unintended consequences of policies to improve the energy efficiency of the UK housing stock. Indoor Built Environ. 2014, 23, 340-352. [CrossRef]

12. Hardin, G. The tragedy of the commons. Science 1968, 162, 1243-1248. [CrossRef] [PubMed]

13. Xing, Y.; Lannon, S.C.; Eames, M. Exploring the use of systems dynamics in sustainable urban retrofit planning. In Urban Retrofitting for Sustainability: Mapping the Transition to 2050; Dixon, T., Ed.; Routledge: Abingdon, UK, 2014; pp. 49-70.

14. Ahern, J. Greenways as planning strategy. Landsc. Urban Plan. 1995, 33, 131-155. [CrossRef]

15. Dunnett, N.; Swanwick, C.; Helen, W. Improving Urban Parks, Play Areas and Green Spaces; Department for Transport, Local Government and the Regions: London, UK, 2002.

16. Young, R.; Zanders, J.; Lieberknecht, K.; Fassman-Beck, E. A comprehensive typology for mainstreaming urban green infrastructure. J. Hydrol. 2014, 519, 2571-2583. [CrossRef]

17. European Commission. Biodiversity Strategy in a Nutshell. 2011. Available online: http://ec.europa.eu/ environment/nature/biodiversity/strategy/index_en.htm (accessed on 7 January 2017).

18. Dover, J.W. Green Infrastructure: Incorporating Plants and Enhancing Biodiversity in Buildings and Urban Environment; Routledge: Oxon, UK, 2015.

19. Tiwary, A.; Williams, I.D.; Heidrich, O.; Namdeo, A.; Bandaru, V.; Calfapietra, C. Development of multi-functional streetscape green infrastructure using a performance index approach. Environ. Pollut. 2016, 208, 209-220. [CrossRef] [PubMed]

20. Koc, C.B.; Osmond, P.; Peters, A. Towards a comprehensive green infrastructure typology: A systematic review of approaches, methods and typologies. Urban Ecosyst. 2016, 1-21. [CrossRef]

21. Howard, E. Garden Cities of To-Morrow; Reprinted 2007; Routledge: London, UK, 1898.

22. Seymour, J. The Complete Book of Self-Sufficiency; Faber: London, UK, 1976.

23. Bates, C. What happened to the self-sufficient people of the 1970s? BBC News Magazine, 12 April 2016.

24. Alexander, C. The Production of Houses; Oxford University Press: New York, NY, USA, 1985.

25. Grant, G.; Engleback, L.; Nicholson, B.; Dusty, G.; Frith, M.; Harvey, P. Green Roofs: Their Existing Status and Potential for Conserving Biodiversity in Urban Areas; English Nature Report; English Nature: Peterborough, UK, 2003.

26. Toronto-City-Planning. Toronto Green Roofs. City Planning Division Telephone Directory. 2015. Available online: http:/ / www1.toronto.ca/wps/portal/contentonly?vgnextoid=3a7a036318061410VgnVCM10000071 d60f89RCRD (accessed on 7 January 2017).

27. Wilebore, R.; Wentworth, J. Urban Green Infrastructure-POST Note; Parliamentary Office of Science and Technology: London, UK, 2013.

28. Allen, W.L. Environmental reviews and case studies: Advancing green infrastructure at all scales: From landscape to site. Environ. Pract. 2012, 14, 17-25. [CrossRef]

29. Gómez-Baggethun, E.; Barton, D.N. Classifying and valuing ecosystem services for urban planning. Ecol. Econ. 2013, 86, 235-245. [CrossRef]

30. European Climate KIC Blue Green Dream Project. 2016. Available online: http://bgd.org.uk/ (accessed on 7 January 2017).

31. Musy, M.; Rodriguez, F.; Gutleben, C.; Rosant, J.-M.; Mestayer, P.; Inard, C.; Long, N. VegDUD Project: Role of vegetation in sustainable urban development. In Proceedings of the 8th International Conference on Urban Climates (ICUC8), Dublin, Ireland, 6-10 August 2012; p. 81.

32. Mcsweeney, J.; Rainham, D.; Johnson, S.A.; Sherry, S.B.; Singleton, J. Indoor nature exposure (INE): A health-promotion framework. Health Promot. Int. 2014, 30, 126-139. [CrossRef] [PubMed]

33. Sundquist, K.; Frank, G.; Sundquist, J. Urbanisation and incidence of psychosis and depression: Follow-up study of 4.4 million women and men in Sweden. Br. J. Psychiatry 2004, 184, 293-298. [CrossRef] [PubMed]

34. Alcock, I.; White, M.P.; Wheeler, B.W.; Fleming, L.E.; Depledge, M.H. Longitudinal effects on mental health of moving to greener and less Green Urban Areas. Environ. Sci. Technol. 2014, 48, 1247-1255. [CrossRef] [PubMed] 
35. Annerstedt, M.; Ostergren, P.-O.; Björk, J.; Grahn, P.; Skärbäck, E.; Währborg, P. Green qualities in the neighbourhood and mental health-Results from a longitudinal cohort study in Southern Sweden. BMC Public Health 2012. [CrossRef] [PubMed]

36. Raanaas, R.K.; Evensen, K.H.; Rich, D.; Sjøstrøm, G.; Patil, G. Benefits of indoor plants on attention capacity in an office setting. J. Environ. Psychol. 2011, 31, 99-105. [CrossRef]

37. Wang, C.; Er, S.-S.; Abdul-Rahman, H. Indoor vertical greenery system in urban tropics. Indoor Built Environ. 2016, 25, 340-356. [CrossRef]

38. Nunez, M.; Oke, T.R. The energy balance of an Urban Canyon. J. Appl. Meteorol. 1977, 16, 11-19. [CrossRef]

39. Givoni, B. Passive and Low Energy Cooling of Buildings; Van Nostrand Reinhold: New York, NY, USA, 1994.

40. Djedjig, R.; Ouldboukhitine, S.; Belarbi, R.; Bozonnet, E. Development and validation of a coupled heat and mass transfer model for green roofs. Int. Commun. Heat Mass Transf. 2012, 39, 752-761. [CrossRef]

41. Mirzaei, P.A. Recent challenges in modeling of urban heat island. Sustain. Cities Soc. 2015, 19, $200-206$. [CrossRef]

42. Nishimura, N.; Nomura, T.; Iyota, H.; Kimoto, S. Novel water facilities for creation of comfortable urban micrometeorology. Sol. Energy 1998, 64, 197-207. [CrossRef]

43. Jim, C.Y.; Tsang, S.W. Biophysical properties and thermal performance of an intensive green roof. Build. Environ. 2011, 46, 1263-1274. [CrossRef]

44. Alcazar, S.S.; Olivieri, F.; Neila, J. Green roofs: Experimental and analytical study of its potential for urban microclimate regulation in Mediterranean-continental climates. Urban Clim. 2015, 17, 304-317. [CrossRef]

45. Jo, H.-K.; McPherson, G.E. Carbon storage and flux in urban residential greenspace. J. Environ. Manag. 1995, 45, 109-133. [CrossRef]

46. Torpy, F.R.; Irga, P.J.; Burchett, M.D. Profiling indoor plants for the amelioration of high $\mathrm{CO}_{2}$ concentrations. Urban For. Urban Green. 2014, 13, 227-233. [CrossRef]

47. Rowntree, R.A.; Nowak, D.J. Quantifying the role of urban forests in removing atmospheric carbon dioxide. J. Arboric. 1991, 17, 269-275.

48. Getter, K.L.; Rowe, D.B.; Robertson, G.P.; Cregg, B.M.; Andresen, J.A. Carbon sequestration potential of extensive green roofs. Environ. Sci. Technol. 2009, 43, 7564-7570. [CrossRef] [PubMed]

49. Klimas, C.; Williams, A.; Hoff, M.; Lawrence, B.; Thompson, J.; Montgomery, J. Valuing ecosystem services and disservices across heterogeneous green spaces. Sustainability 2016, 8, 853. [CrossRef]

50. Savard, J.P.L.; Clergeau, P.; Mennechez, G. Biodiversity concepts and urban ecosystems. Landsc. Urban Plan. 2000, 48, 131-142. [CrossRef]

51. Farinha-Marques, P.; Lameiras, J.M.; Fernandes, C.; Silva, S.; Guilherme, F. Urban biodiversity: A review of current concepts and contributions to multidisciplinary approaches. Innov. Eur. J. Soc. Sci. Res. 2011, 24, 247-271. [CrossRef]

52. Whitford, V.; Handley, J.; Ennos, R. City form and natural process-indicators for the ecological performance of urban areas. Landsc. Urban Plan. 2001, 57, 91-103. [CrossRef]

53. Baldock, K.C.R.; Goddard, M.A.; Hicks, D.M.; Kunin, W.E.; Mitschunas, N.; Osgathorpe, L.M.; Potts, S.G.; Robertson, K.M.; Scott, A.V.; Stone, G.N.; et al. Where is the UK's pollinator biodiversity? The importance of urban areas for flower-visiting insects. Proc. R. Soc. B Biol. Sci. 2015, 282, 20142849. [CrossRef] [PubMed]

54. Mason, C.F. Avian species richness and numbers in the built environment: Can new housing developments be good for birds? Biodivers. Conserv. 2006, 15, 2365-2378. [CrossRef]

55. Beumer, C.; Martens, P. Biodiversity in my (back)yard: Towards a framework for citizen engagement in exploring biodiversity and ecosystem services in residential gardens. Sustain. Sci. 2015, 10, 87-100. [CrossRef]

56. Silvertown, J. A new dawn for citizen science. Trends Ecol. Evol. 2009, 24, 467-471. [CrossRef] [PubMed]

57. Vineyard, D.; Ingwersen, W.W.; Hawkins, T.R.; Xue, X.; Demeke, B.; Shuster, W. Comparing green and grey infrastructure using life cycle cost and environmental impact: A rain garden case study in Cincinnati, $\mathrm{OH}$. JAWRA J. Am. Water Resour. Assoc. 2015, 51, 1342-1360. [CrossRef]

58. Ellis, J.B. Sustainable surface water management and green infrastructure in UK urban catchment planning. J. Environ. Plan. Manag. 2012, 56, 24-41. [CrossRef]

59. Rowe, D.B. Green roofs as a means of pollution abatement. Environ. Pollut. 2011, 159, 2100-2110. [CrossRef] [PubMed] 
60. Stovin, V.; Vesuviano, G.; Kasmin, H. The hydrological performance of a green roof test bed under UK climatic conditions. J. Hydrol. 2012, 414-415, 148-161. [CrossRef]

61. Versini, P.-A.; Jouve, P.; Ramier, D.; Berthier, E.; de Gouvello, B. Use of green roofs to solve storm water issues at the basin scale-Study in the Hauts-de-Seine County (France). Urban Water J. 2016, 9006, 1-10. [CrossRef]

62. Speak, F.; Rothwell, J.; Lindley, S.; Smith, C. Urban particulate pollution reduction by four species of green roof vegetation in a UK city. Atmos. Environ. 2012, 61, 283-293. [CrossRef]

63. Beecham, S.; Razzaghmanesh, M. Water quality and quantity investigation of green roofs in a dry climate. Water Res. 2015, 70, 370-384. [CrossRef] [PubMed]

64. Despommier, D. The Vertical Farm: Feeding the World in the 21st Century; Thomas Dunne Books: New York, NY, USA, 2010.

65. Thomaiera, S.; Spechta, K.; Dietrich, H.; Axel, D.; Rosemarie, S.; van den Dobbelsteen, A.; Magdalena, S. Farming in and on urban buildings: Present practice and specific novelties of Zero-Acreage Farming (ZFarming). Renew. Agric. Food Syst. 2015, 30, 43-54. [CrossRef]

66. Viljoen, A.; Howe, J. Continuous Productive Urban Landscape (CPUL); Architectural Press: New York, NY, USA, 2005.

67. Kozai, M.T.T.; Niu, G. Plant Factory: An Indoor Vertical Farming System for Efficient Quality Food Production; Academic Press: Cambridge, MA, USA, 2015.

68. Tomalty, R.; Komorowski, B.; Doiron, D. The Monetary Value of the Soft Benefits of Green Roofs; Final Report; Canada Mortgage and Housing Corporation (CMHC): Ottawa, ON, Canada, 2010.

69. Ksiazek, K.; Tonietto, R.; Ascher, J.S. Ten bee species new to green roofs in the Chicago area. Mich. Entomol. Soc. 2014, 47, 87-92.

70. Tonietto, R.; Fant, J.; Ascher, J.; Ellis, K.; Larkin, D. Landscape and Urban Planning A comparison of bee communities of Chicago green roofs, parks and prairies. Landsc. Urban Plan. 2011, 103, 102-108. [CrossRef]

71. MacIvor Scott, J.; Ruttan, A.; Salehi, B. Exotics on exotics: Pollen analysis of urban bees visiting Sedum on a green roof. Urban Ecosyst. 2014, 18, 419-430. [CrossRef]

72. Hawkins, J.; de Vere, N.; Griffith, A.; Ford, C.R.; Allainguillaume, J.; Hegarty, M.J.; Baillie, L.; Adams-Groom, B. Using DNA metabarcoding to identify the floral composition of honey: A new tool for investigating honey bee foraging preferences. PLOS ONE 2015, 10, e0134735. [CrossRef] [PubMed]

73. Wolverton, B.; Jhonson, A.; Training, O.; Training, P.; Darin, C.; Training, R.O.; Kimberly, M.; Deepa, G.; Board, E.; Principal, E.; et al. Interior Landscape Plants for Indoor Air Pollution Abatement; National Aeronautics and Space Administration (NASA): Washington, DC, USA, 1989; pp. 1-5.

74. Rosenfeld, A.H.; Akbari, H.; Romm, J.J.; Pomerantz, M. Cool communities: Strategies for heat island mitigation and smog reduction. Energy Build. 1998, 28, 51-62. [CrossRef]

75. Pugh, T.A.M.; MacKenzie, A.R.; Whyatt, J.D.; Hewitt, C.N. Effectiveness of green infrastructure for improvement of air quality in urban street canyons. Environ. Sci. Technol. 2012, 46, 7692-7699. [CrossRef] [PubMed]

76. Speak, F.; Rothwell, J.J.; Lindley, S.J.; Smith, C.L. Metal and nutrient dynamics on an aged intensive green roof. Environ. Pollut. 2014, 184, 33-43. [CrossRef] [PubMed]

77. Environment Australia (EA). BTEX Personal Exposure Monitoring in Four Australian Cities; Technical Paper No. 6; Environment Australia: Canberra, Australia, 2003.

78. Irga, P.J.; Torpy, F.R.; Burchett, M.D. Can hydroculture be used to enhance the performance of indoor plants for the removal of air pollutants? Atmos. Environ. 2013, 77, 267-271. [CrossRef]

79. Owen, S.M.; Mackenzie, A.R.; Stewart, H.; Donovan, R.; Hewitt, C.N. Biogenic volatile organic compound (VOC) emission estimates from an urban tree canopy from an urban tree canopy. Ecol. Appl. 2013, 13, 927-938. [CrossRef]

80. Torpy, F.R. Reducing indoor air pollutants through biotechnology. In Biotechnologies and Biomimetics for Civil Engineering; Springer: Cham, Switzerland, 2014; pp. 181-210.

81. Azkorra, Z.; Pérez, G.; Coma, J.; Cabeza, L.F.; Bures, S.; Álvaro, J.E.; Erkoreka, A.; Urrestarazu, M. Evaluation of green walls as a passive acoustic insulation system for buildings. Appl. Acoust. 2015, 89, 46-56. [CrossRef]

82. Connelly, M.; Hodgson, M. Experimental investigation of the sound absorption characteristics of vegetated roofs. Build. Environ. 2015, 92, 335-346. [CrossRef]

83. D'Alessandro, F.; Asdrubali, F.; Mencarelli, N. Experimental evaluation and modelling of the sound absorption properties of plants for indoor acoustic applications. Build. Environ. 2015, 95, 913-923. [CrossRef] 
84. Adams, M.; Cox, T.; Moore, G.; Croxford, B.; Refaee, M.; Sharples, S. Sustainable soundscapes: Noise policy and the urban experience. Urban Stud. 2006, 43, 2385-2398. [CrossRef]

85. Falxa-Raymond, N.; Svendsen, E.; Campbell, L.K. From job training to green jobs: A case study of a young adult employment program centered on environmental restoration in New York City, USA. Urban For. Urban Green. 2013, 12, 287-295. [CrossRef]

86. Peng, L.L.H.; Jim, C.Y. Economic evaluation of green-roof environmental benefits in the context of climate change: The case of Hong Kong. Urban For. Urban Green. 2015, 14, 554-561. [CrossRef]

87. Chang, K.F.; Chou, P.C. Measuring the influence of the greening design of the building environment on the urban real estate market in Taiwan. Build. Environ. 2010, 45, 2057-2067. [CrossRef]

88. Elmqvist, T.; Setala, H.; Handel, S.N.; van der Ploeg, S.; Aronson, J.; Blignaut, J.N.; Gemez-Baggethun, E.; Nowak, D.J.; Kronenberg, J.; de Groot, R. Benefits of restoring ecosystem services in urban areas. Curr. Opin. Environ. Sustain. 2015, 14, 101-108. [CrossRef]

89. De Groot, R.; Brander, L.; van der Ploeg, S.; Costanza, R.; Bernard, F.; Braat, L.; Christie, M.; Crossman, N.; Ghermandi, A.; Hein, L.; et al. Global estimates of the value of ecosystems and their services in monetary units. Ecosyst. Serv. 2012, 1, 50-61. [CrossRef]

90. Kim, J.; Kaplan, R. Physical and psychological factors in sense of community: New urbanist kentlands and nearby orchard village. Environ. Behav. 2004, 36, 313-340. [CrossRef]

91. Peters, K.; Elands, B.; Buijs, A. Social interactions in urban parks: Stimulating social cohesion? Urban For. Urban Green. 2010, 9, 93-100. [CrossRef]

92. Scholte, S.S.K.; van Teeffelen, A.J.A.; Verburg, P.H. Integrating socio-cultural perspectives into ecosystem service valuation: A review of concepts and methods. Ecol. Econ. 2015, 114, 67-78. [CrossRef]

93. Hunter, A.J.; Luck, G.W. Defining and measuring the social-ecological quality of urban greenspace: A semi-systematic review. Urban Ecosyst. 2015, 18, 1139-1163. [CrossRef]

94. McMillen, H.; Campbell, L.K.; Svendsen, E.S.; Reynolds, R. Recognizing stewardship practices as indicators of social resilience: In living memorials and in a community garden. Sustainability 2016, 8, 775. [CrossRef]

95. Kim, G. The public value of urban vacant land: Social responses and ecological value. Sustainability 2016, 8 , 486. [CrossRef]

96. Jensen, M.H. Hydroponics worldwide. Acta Hortic. 1999, 481, 719-729. [CrossRef]

97. Love, D.C.; Uhl, M.S.; Genello, L. Energy and water use of a small-scale raft aquaponics system in Baltimore, Maryland, United States. Aquac. Eng. 2015, 68, 19-27. [CrossRef]

98. Davis, M.M.; Hirmer, S. The potential for vertical gardens as evaporative coolers: An adaptation of the 'Penman Monteith Equation'. Build. Environ. 2015, 92, 135-141. [CrossRef]

99. La Roche, P.; Berardi, U. Comfort and energy savings with active green roofs. Energy Build. 2014, 82, 492-504. [CrossRef]

100. Jim, C.Y. Greenwall classification and critical design-management assessments. Ecol. Eng. 2015, 77, 348-362. [CrossRef]

101. Charoenkit, S.; Yiemwattana, S. Living walls and their contribution to improved thermal comfort and carbon emission reduction: A review. Build. Environ. 2016, 105, 82-94. [CrossRef]

102. Perini, K.; Ottelé, M.; Fraaij, A.L.A.; Haas, E.M.; Raiteri, R. Vertical greening systems and the effect on air flow and temperature on the building envelope. Build. Environ. 2011, 46, 2287-2294. [CrossRef]

103. Yeang, K. Highrise design for hot humid places. Build. Res. Inf. 1991, 19, 274-281. [CrossRef]

104. Hart, S.; Yeang, K.; Littlefield, D. Ecoarchitecture: The Work of Ken Yeang; Wiley: Hoboken, NJ, USA, 2011.

105. Swanwick, C. Society's attitudes to and preferences for land and landscape. Land Use Policy 2009, $26,62-75$. [CrossRef]

106. Chocat, B.; Ashley, R.; Marsalek, J.; Matos, M.R.; Rauch, W.; Schilling, W.; Urbonas, B. Toward the sustainable management of urban storm-water. Indoor Built Environ. 2007, 16, 273-285. [CrossRef]

107. Trowbridge, P.J.; Bassuk, N.L. Trees in Urban Landscape: Site Assessment, Design and Installation; John Wiley \& Sons: Hoboken, NJ, USA, 2004.

108. Greenroofs. The International Greenroof E Greenwall Projects Database; Greenroofs.com., LLC.: Alpharetta, GA, USA, 2016.

109. The International Green Roof Association (IGRA). Green Roof Database. International Green Roof City Network. 2016. Available online: http://www.igra-world.com/green_roofs_worldwide/green_roof_ database.php (accessed on 16 May 2016). 
110. De Groot, R.S.; Alkemade, R.; Braat, L.; Hein, L.; Willemen, L. Challenges in integrating the concept of ecosystem services and values in landscape planning, management and decision making. Ecol. Complex. 2010, 7, 260-272. [CrossRef]

111. Choi, H.S.; Lee, G.S. Planning Support Systems (PSS)-based spatial plan alternatives and environmental assessment. Sustainability 2016, 8, 286. [CrossRef]

112. Royal Botanic Gardens (RBG) Kew. State of the World's Plants 2016. Available online: https:/ / stateoftheworldsplants.com/report/sotwp_2016.pdf (accessed on 7 January 2017).

113. Dunnett, N.; Noël, K. Planting Green Roofs and Living Walls; Timber Press: Portland, OR, USA, 2008.

114. Calkings, M. The Sustainable Sites Handbook: A Complete Guide to the Principles, Strategies, and Best Practices for Sustainable Landscapes; Wiley: Hoboken, NJ, USA, 2012.

115. Blanusa, T.; Monteiro, M.M.V.; Fantozzi, F.; Vysini, E.; Li, Y.; Cameron, R.W.F. Alternatives to Sedum on green roofs: Can broad leaf perennial plants offer better 'cooling service'? Build. Environ. 2013, 59, 99-106. [CrossRef]

116. Cameron, R.W.F.; Taylor, J.E.; Emmett, M.R. What's 'cool' in the world of green facades? How plant choice influences the cooling properties of green walls. Build. Environ. 2014, 73, 198-207. [CrossRef]

117. White, E.V.; Gatersleben, B. Greenery on residential buildings: Does it affect preferences and perceptions of beauty? J. Environ. Psychol. 2011, 31, 89-98. [CrossRef]

118. Cameron, R.W.F.; Blanuša, T. Green infrastructure and ecosystem services-Is the devil in the detail? Ann. Bot. 2016, 118, 377-391. [CrossRef] [PubMed]

119. Eksi, M.; Rowe, D.B.; Fernández-Cañero, R.; Cregg, B.M. Effect of substrate compost percentage on green roof vegetable production. Urban For. Urban Green. 2015, 14, 315-322. [CrossRef]

120. Brown, C.; Lundholm, J. Microclimate and substrate depth influence green roof plant community dynamics. Landsc. Urban Plan. 2015, 143, 134-142. [CrossRef]

121. Sailor, D.J.; Hagos, M. An updated and expanded set of thermal property data for green roof growing media. Energy Build. 2011, 43, 2298-2303. [CrossRef]

122. Pérez, G.; Vila, A.; Rincón, L.; Solé, C.; Cabeza, L.F. Use of rubber crumbs as drainage layer in green roofs as potential energy improvement material. Appl. Energy 2012, 97, 347-354. [CrossRef]

123. Pérez, G.; Rincón, L.; Vila, A.; González, J.M.; Cabeza, L.F. Green vertical systems for buildings as passive systems for energy savings. Appl. Energy 2011, 88, 4854-4859. [CrossRef]

124. Pérez, G.; Rincón, L.; Vila, A.; González, J.M.; Cabeza, L.F. Behaviour of green facades in Mediterranean Continental climate. Energy Convers. Manag. 2011, 52, 1861-1867. [CrossRef]

125. Schumann, L.; Tilley, D. Modeled effects of roof vine canopy on indoor building temperatures in July. In Proceedings of the 6th North American Green Roof Conference: Greening Rooftops for Sustainable Communities, Baltimore, MD, USA, 1-3 May 2008.

126. Ottelé, M.; Perini, K.; Fraaij, A.L.A.; Haas, E.M.; Raiteri, R. Comparative life cycle analysis for green façades and living wall systems. Energy Build. 2011, 43, 3419-3429. [CrossRef]

127. Ouldboukhitine, S.E.; Spolek, G.; Belarbi, R. Impact of plants transpiration, grey and clean water irrigation on the thermal resistance of green roofs. Ecol. Eng. 2014, 67, 60-66. [CrossRef]

128. Van Mechelen, C.; Dutoit, T.; Hermy, M. Adapting green roof irrigation practices for a sustainable future: A review. Sustain. Cities Soc. 2015, 19, 74-90. [CrossRef]

129. Bailey, R.M. Spatial and temporal signatures of fragility and threshold proximity in modelled semi-arid vegetation. Proc. R. Soc. B Biol. Sci. 2010, 278, 1064-1071. [CrossRef] [PubMed]

130. Rayner, J.P.; Raynor, K.J.; Williams, N.S.G. Façade greening: A case study from Melbourne, Australia. In Proceedings of the II International Conference on Landscape and Urban Horticulture, Bologna, Italy, 9-13 June 2009.

131. Pauleit, S.; Jones, N.; Garcia-Martin, G.; Garcia-Valdecantos, J.L.; Rivière, L.M.; Vidal-Beaudet, L.; Bodson, M.; Randrup, T.B. Tree establishment practice in towns and cities-Results from a European survey. Urban For. Urban Green. 2002, 1, 83-96. [CrossRef]

132. Diamant, E.; Waterhouse, A. Gardening and belonging: Reflections on how social and therapeutic horticulture may facilitate health, wellbeing and inclusion. Br. J. Occup. Ther. 2010, 73, 84-88. [CrossRef]

133. Vijayaraghavan, K. Green roofs: A critical review on the role of components, benefits, limitations and trends. Renew. Sustain. Energy Rev. 2016, 57, 740-752. [CrossRef] 
134. Herringshaw, C.J.; Thompson, J.R.; Stewart, T.W. Learning about restoration of urban ecosystems: A case study integrating public participation, stormwater management, and ecological research. Urban Ecosyst. 2010, 13, 535-562. [CrossRef]

135. Roy, H.E.; Pocock, M.J.O.; Preston, C.D.; Roy, D.B.; Savage, J.; Tweddle, J.C.; Robinson, L.D. Understanding Citizen Science and Environmental Monitoring: Final Report on Behalf of UK-Environmental Observation Framework; NERC Centre for Ecology \& Hydrology and Naturel History Museum: Wallingford, UK, 2012.

136. Castell, N.; Kobernus, M.; Liu, H.Y.; Schneider, P.; Lahoz, W.; Berre, A.J.; Noll, J. Mobile technologies and services for environmental monitoring: The Citi-Sense-MOB approach. Urban Clim. 2015, 14, 370-382. [CrossRef]

137. Goçer, O.; Hua, Y.; Goçer, K. Completing the missing link in building design process: Enhancing post-occupancy evaluation method for effective feedback for building performance. Build. Environ. 2015, 89, 14-27. [CrossRef]

138. Wootton-Beard, P.; Xing, Y.; Prabhakaran, R.T.D.; Robson, P.; Bosch, M.; Thornton, J.M.; Ormondroyd, G.A.; Jones, P.; Donnison, I. Reviews: Improving the impact of plant science on urban planning and design. Buildings 2016, 6, 48. [CrossRef]

139. Wilson, E.O. Biophilia: The Human Bond with Other Species; Harvard University Press: Cambridge, MA, USA, 1984.

(C) 2017 by the authors; licensee MDPI, Basel, Switzerland. This article is an open access article distributed under the terms and conditions of the Creative Commons Attribution (CC BY) license (http:/ / creativecommons.org/licenses/by/4.0/). 